\title{
Encapsulation of mepivacaine prolongs the anal- gesia provided by sciatic nerve blockade in mice
} [La micro-encapsulation de la mépivacaïne prolonge l'analgésie fournie par le bloc du nerf sciatique chez la souris]

\author{
Daniele R. de Araujo, ${ }^{*}$ Cíntia M.S. Cereda, ${ }^{*}$ Giovana B. Brunetto, ${ }^{*}$ Luciana M.A. Pinto PhD, ${ }^{*}$
} Maria Helena A. Santana PhD,$\dagger$ Eneida de Paula PhD*

Purpose: Liposomal formulations of local anesthetics (LA) are able to control drug-delivery in biological systems, prolonging their anesthetic effect. This study aimed to prepare, characterize and evaluate in vivo drug-delivery systems, composed of large unilamellar liposomes (LUV), for bupivacaine (BVC) and mepivacaine (MVC).

Methods: BVC and MVC hydrochloride were encapsulated into LUV $(0.4 \mu \mathrm{m})$ composed of egg phosphatidylcholine, cholesterol and $\alpha$-tocopherol (4:3:0.07 molar ratio) to final concentrations of $0.125,0.25,0.5 \%$ for BVC and 0.5, I, 2\% for MVC. Motor function and antinociceptive effects were evaluated by sciatic nerve blockade induced by liposomal and plain formulations in mice.

Results: Liposomal formulations modified neither the intensity nor the duration of motor blockade compared to plain solutions. Concerning sensory blockade, liposomal BVC $\left(B C_{L U V}\right)$ showed no advantage relatively to the plain BVC injection while liposomal MVC $\left(M_{V} C_{\text {LUV }}\right)$ improved both the intensity (1.4-1.6 times) and the duration of sensory blockade ( $1.3-1.7$ times) in comparison to its plain solution $(P<0.00 \mathrm{I})$ suggesting an increased lipid solubility, availability and controlled-release of the drug at the site of injection.

Conclusion: $M V C_{L U V}$ provided a LA effect comparable to that of BVC. We propose $M V C_{\text {LUV }}$ drug delivery as a potentially new therapeutic option for the treatment of acute pain since the formulation enhances the duration of sensory blockade at lower concentrations than those of plain MVC.

\begin{abstract}
Objectif : Des préparations liposomales d'anesthésiques locaux (AL) peuvent contrôler l'administration de médicaments dans les systèmes biologiques, prolongeant leur effet anesthésique. Notre objectif était de préparer, caractériser et évaluer des systèmes d'administration de médicaments in vivo, composés de gros liposomes unilamellaires (GLU), pour la bupivacaïne (BVC) et la mépivacaïne (MVC).
\end{abstract}

Méthode : Le chlorhydrate de BVC et de MVC a été mis en capsules dans des GLU $(0,4 \mu \mathrm{m})$ composés de lécithine d'œuf, de cholestérol et de $\alpha$-tocophérol (concentration molaire 4:3:0,07) pour obtenir des concentrations finales de 0,125,0,25,0,5\% pour la BVC et 0,5, I, $2 \%$ pour la MVC. La fonction motrice et les effets antinociceptifs ont été évalués par le blocage du nerf sciatique induit par des préparations liposomales et des préparations simples chez des souris.

Résultats : Les préparations liposomales, comparées aux préparations simples, n'ont pas modifié l'intensité ni la duré du bloc moteur. Quant au bloc sensitif, la BVC liposomale (BVC LUV) n'a pas présenté d'avantage par rapport à l'injection de BVC simple tandis que la MVC liposomale $\left(M V C_{\text {LuV }}\right)$ a amélioré l'intensité ( I,4-1,6 fois) et la duré du bloc sensitif ( I,3-1,7 fois) comparée à la solution simple $(P<0,001)$. Ce qui laisse croire à une meilleure solubilité lipidique, à une disponibilité accrue et à une meilleure administration du médicament à libération contrôlée au site de l'injection.

Conclusion : La MVC $C_{\text {LUV }}$ fournit un effet AL comparable à celui de la BVC. Nous proposons l'administration de $M V C_{\text {LUV }}$ comme un nouveau choix possible de traitement de la douleur aiguë, puisque la préparation augmente la durée du bloc sensitif à des concentrations plus faibles que celles de la MVC simple.

From the Department of Biochemistry, ${ }^{*}$ Institute of Biology, State University of Campinas; and the Department of Biotechnological Process, $†$ Faculty of Chemical Engineering - UNICAMP, Campinas, Sao Paulo, Brazil.

Address correspondence to: Dr. Eneida de Paula, Departamento de Bioquímica, Instituto de Biologia, UNICAMP, C.P. 6109, CEP

13083-970, Campinas, SP, Brazil. Phone: +55 193788 6143; Fax: +55 193788 6129; E-mail: depaula@unicamp.br

Accepted for publication November 4, 2003.

Revision accepted February 18, 2004.

D.R. de Araujo is the recipient of a fellowship from CAPES (Comissão de Aperfeiçoamento de Pessoal do Ensino Superior) and E. de Paula of a research fellowship from CNPq. This work was also supported by FAPESP (Proc. 96/04159-8, 01/12476-2). 
$\mathrm{B}$ UPIVACAINE (BVC) and mepivacaine (MVC) are local anesthetics (LA) that are used worldwide for pain relief. ${ }^{1}$ BVC is the drug of choice in surgery due to its moderate onset and long duration of action, as well as its significant differentiation between motor and sensory blockade. Although chemically related to BVC, MVC has lower systemic and cardiotoxicity, induces rapid onset of anesthesia but has a restrained duration of action. $^{2}$

The development of LA formulations in carriers such as liposomes - offers the possibility to control drug delivery in biological systems, prolonging their anesthetic effect. ${ }^{3}$ Because of their amphiphilic nature, when bound to model membrane systems, LA reside mainly in the bilayer region ${ }^{4-6}$ while another fraction remains in the aqueous core. ${ }^{7}$ We can take advantage of this strong interaction between LA and liposomes to control the release of the drug, in order to obtain a prolonged duration of action and reduce central nervous and/or cardiovascular system toxicity. ${ }^{8,9}$

We aimed to prepare, characterize and evaluate two drug-delivery systems for the amino-amide anesthetics BVC and MVC. Motor and sensory blockade in mice were used to compare liposomal formulations and the LA preparations available commercially.

\section{Methods}

BVC and MVC hydrochlorides were donated by Cristália Prod. Quím Farm Ltda (Itapira, SP, Brazil). Egg phosphatidylcholine, cholesterol, $\alpha$-tocopherol and HEPES buffer were purchased from Sigma Chemical Company (St. Louis, MO, USA). BVC and MVC solutions were prepared in $0.9 \%$ saline ( $154 \mathrm{mM}$ $\mathrm{NaCl}$ ), whereas LA liposomal formulations were prepared in $20 \mathrm{mM}$ HEPES buffer plus $154 \mathrm{mM} \mathrm{NaCl}$ at pH 7.4.

Preparation and in vitro tests - including liposome size distribution, partition coefficient determination and release kinetics - are presented in the Appendix available as Additional Material at www.cja-jca.org.

In vivo efficacy studies were performed using groups of eight to ten male Swiss adult albino mice, weighing 30 to $35 \mathrm{~g}$ and obtained from CEMIB-UNICAMP (Centro de Bioterismo - State University of Campinas UNICAMP, Campinas, SP, Brazil). The protocol was approved by the UNICAMP Institutional Animal Care and Use Committee (Protocol 322-1) which follows the recommendations of the Guide for the Care and Use of Laboratory Animals.

Animals selected for the motor blockade test were treated by infiltration $(0.1 \mathrm{~mL})$ with plain and liposomal formulations of BVC and MVC. The needle was inserted into the popliteal space on the posterior surface of the knee, in the area of the sciatic nerve. Motor and sensory blockade were assessed simultaneously. Drugs were given in a randomized order (animals were assigned to the groups by using a previous numbering list) and the same investigator performed all the experiments. The animals were observed for $24 \mathrm{hr}$ after treatment in order to detect possible toxic (systemic, such as seizures or obits) effects or nerve damage (lack of recovery of normal movement on the injected limb) caused by the procedure. The experimental groups included: control (treated with drugfree liposomes - large unilamellar liposomes (LUV) or plain LA solutions - $\mathrm{BVC}_{\text {plain }}$ or $\mathrm{MVC}_{\text {plain }}$ ) and liposomal $\left(\mathrm{BVC}_{\mathrm{LUV}}\right.$ or $\left.\mathrm{MVC}_{\mathrm{LUV}}\right)$ treated mice. The sciatic nerve model was used to assess motor blockade. Before starting the experiment, the ability of each mouse to walk normally with four limbs on both the top and inverted side of a wire mesh screen ( $1 \mathrm{~mm}$ diameter wire, $5 \mathrm{~mm}$ mesh) was evaluated. Only animals that showed this behaviour were selected for the experiment. LA activity was assessed by the loss of motor control in the injected limb with the scores: 0 (normal movement); l (unable to flex the limb completely); and 2 (total paralysis). ${ }^{10}$ Any animal that could not use the injected limb to walk normally on the top and on the inverted wire mesh screen was considered to have a positive response to local anesthesia. The efficacy of motor blockade was evaluated every minute, from one to five minutes, and thereafter every ten minutes up to one hour following the injection. Latency (time between injection and the loss of motor function), time to reach the maximum score $\left(\mathrm{T}_{\max }\right)$, time for motor function recovery and the total LA effect (estimated by the area under the effect $v$ s time curve and expressed by score/hour; AUC) ${ }^{11}$ were evaluated using Origin 6.0 (Microcal ${ }^{\mathrm{TM}}$ Software, Inc., Northampton, MA, USA).

Evaluation of sensory blockade was done by the paw pressure test or mechanical nociception. ${ }^{12}$ Pain was measured with an analgesimeter (Ugo Basile, Varese, Italy), which exerts an increasing - at a constant rate - force (in grams) on the paw (Figures 1A and B). In order to avoid analgesia induced by excessive stress, each animal was gently wrapped in a small towel so that only the limbs and head were free. The withdrawal reflex was considered representative of the pain threshold or paw withdrawal threshold to pressure (PWTP). The baseline of the PWTP test was measured before injecting vehicle or drugs, in order to determine the pain threshold of the animal. Baseline values of 30 to $50 \mathrm{~g}$ were selected as the pain threshold and animals that presented lower or higher values 
TABLE Latency, $\mathrm{T}_{\max }$, time for recovery and total effect of motor blockade (AUC) for plain and liposomal bupivacaine and mepivacaine formulations

\begin{tabular}{|c|c|c|c|c|c|}
\hline Groups & $\begin{array}{l}\text { Concentration } \\
(\%)\end{array}$ & $\begin{array}{l}\text { Latency } \\
\text { (min) }\end{array}$ & $\begin{array}{l}T_{\max } \\
\text { (min) }\end{array}$ & $\begin{array}{l}\text { Time for recovery } \\
\text { (min) }\end{array}$ & $\begin{array}{l}A U C \\
(\text { score/hr) }\end{array}$ \\
\hline \multirow{3}{*}{$\mathrm{BVC}_{\text {plain }}$} & 0.125 & $1(1-2)$ & $3(2-3)$ & $20.0(-)$ & $22.5(19.0-28.0)$ \\
\hline & 0.25 & $1(1-2)$ & $2(2-3)$ & $40.0(30.0-40.0)$ & $41.0(37.0-48.0)$ \\
\hline & 0.5 & $1(-)$ & $1(-)^{a^{a * *}}$ & $50.0(30.0-60.0)^{\mathrm{a}^{* * *}}$ & $58.0(50.0-88.0)^{\mathrm{a}^{\star *}}$ \\
\hline \multirow[t]{3}{*}{$\mathrm{BVC}_{\mathrm{LUV}}$} & 0.125 & $1(1-2)$ & $4(2-5)$ & $20.0(20.0-30.0)$ & $21.5(17.0-38.0)$ \\
\hline & 0.25 & $1(-)$ & $2.5(1-3)$ & $40.0(30.0-50.0)$ & $57.0(19.0-78.0)$ \\
\hline & 0.5 & $1(-)$ & $1(1-2)^{b^{\star \star}}$ & $40.0(40.0-50.0)^{\mathrm{b}^{*}}$ & $68.0(58.0-98.0)^{\mathrm{b}^{\star * *}}$ \\
\hline \multirow[t]{3}{*}{$\mathrm{MVC}_{\text {plain }}$} & 0.5 & $1(1-2)$ & $2(2-3)$ & $25.0(20.0-40.0)$ & $28.5(20.0-58.0)$ \\
\hline & 1 & $1(-)$ & $2(1-4)$ & $30.0(20.0-40.0)$ & $37.5(27.0-48.0)$ \\
\hline & 2 & $1(-)$ & $1.5(1-3)$ & $40.0(40.0-50.0)^{\mathrm{c}^{\star}}$ & $68.0(39.0-78.0)^{\mathrm{c}^{*}}$ \\
\hline \multirow[t]{3}{*}{$\mathrm{MVC}_{\mathrm{LUV}}$} & 0.5 & $1(1-2)$ & $2.5(1-3)$ & $20.0(20.0-40.0)$ & $27.0(19.0-38.0)$ \\
\hline & 1 & $1(-)$ & $2.5(1-3)$ & $40.0(30.0-40.0)$ & $47.5(37.0-58.0)$ \\
\hline & 2 & $1(-)$ & $1(1-3)$ & $40.0(40.0-50.0)^{\mathrm{d}^{\star \star}}$ & $58.0(47.0-78.0)^{\mathrm{d}^{\star *}}$ \\
\hline
\end{tabular}

Data are expressed as median (minimum-maximum; $n=$ eight per group). ${ }^{*} P<0.05 ;{ }^{*} P<0.01 ;{ }^{* *} P<0.001$. Tmax $=$ time to reach the maximum score; $\mathrm{BVC}=$ bupivacaine; $\mathrm{MVC}=$ mepivacaine; $\mathrm{LUV}=$ large unilamellar liposomes. Statistical differences between: $\mathrm{a}, 0.5 \%$ $\mathrm{BVC}_{\text {plain }}$ and $0.125 \% \mathrm{BVC}_{\text {plain }} ; \mathrm{b}, 0.5 \% \mathrm{BVC}_{\mathrm{LUV}}$ and $0.125 \% \mathrm{BVC}_{\mathrm{LUV}} ; \mathrm{c}, 2 \% \mathrm{MVC}_{\text {plain }}$ and $0.5 \% \mathrm{MVC}_{\text {plain }} ; \mathrm{d}, 2 \% \mathrm{MVC}_{\mathrm{LUV}}$ and $0.5 \%$ $\mathrm{MVC}_{\mathrm{LUV}}$. $\mathrm{AUC}=$ areas under the curve.

than that of baseline were excluded. The established antinociception cut-off value was $150 \mathrm{~g}$, considered to be representative of the anesthetic state. After drug or vehicle administration, measurements were carried out at intervals of $15 \mathrm{~min}$ during the first hour, $30 \mathrm{~min}$ in the second and third hour and finally $60 \mathrm{~min}$ up to five hours after treatment.

Size distribution of liposomes was compared by the one-way analysis of variance (one-way ANOVA) and in vitro release tests were analyzed by unpaired t test. Motor block data (latency, $\mathrm{T}_{\max }$, time for recovery and AUC) were analyzed by the Kruskall-Wallis test and expressed as medians (minimum and maximum limits). Sensory blockade data were analyzed by one-way ANOVA with Tukey-Kramer as a post hoc test. Statistical significance was defined as $P<0.05$.

\section{Results}

Motor function was affected by the injection of BVC and MVC (plain or liposomal) so that the mice lost motor control in the injected limb. The LUV group did not show any motor blockade. Latency, $\mathrm{T}_{\max }$, time for recovery and total LA effects were compared between all the experimental groups (Table). Dosedependent effects were observed on motor blockade for liposomal and plain formulations of LA. No significant differences were observed between liposomal and plain formulations for any of the LA.
$\mathrm{T}_{\max }$, time for recovery and AUC were greater with 0.5 compared to $0.125 \% \mathrm{BVC}_{\text {plain }}(P<0.001)$. Similar effects were observed between $0.5 \%$ and $0.125 \%$ $\mathrm{BVC}_{\mathrm{LUV}}$ for the same variables $(P<0.01, P<0.05$ and $P<0.001$, respectively).

Time for recovery and AUC were greater with $2 \%$ compared to $0.5 \% \mathrm{MVC}_{\text {plain }}(P<0.05)$ and with $2 \%$ compared to $0.5 \% \mathrm{MVC}_{\mathrm{LUV}}(P<0.01)$.

Equivalent effects were found between $0.25 \%$ $\mathrm{BVC}_{\mathrm{LUV}}$ and $0.5 \% \quad \mathrm{BVC}_{\text {plain }}$ and between $0.5 \%$ $\mathrm{MVC}_{\mathrm{LUV}}$ and $1 \% \mathrm{MVC}_{\text {plain }}$, both in time for recovery and AUC.

Dose-response relationships were established for BVC and MVC (plain and liposomal) in mice by the PWTP test (Figures 2 and 3). Time-course of analgesia was recorded for the groups: drug-free LUV, BVC or $\mathrm{MVC}$ plain and $\mathrm{BVC}_{\mathrm{LUV}}$ or $\mathrm{MVC}_{\mathrm{LUV}}$, at three different concentrations of the anesthetics. Figures 2 and 3 show that vehicle infiltration in the region of the sciatic nerve did not modify baseline values $(30-50 \mathrm{~g})$ of the pain threshold, while all LA formulations tested were different from their control-vehicle groups $(P<$ $0.001)$ regarding sensory blockade.

$B_{\text {BUV }}$ showed similar intensity (evaluated from the average response on the PWTP test) and duration of sensory blockade when compared to $\mathrm{BVC}_{\text {plain }}$. A higher intensity of sensory blockade were found only at $15 \mathrm{~min}$ for $0.125 \% \mathrm{BVC}_{\mathrm{LUV}}(P<0.01$; Figure $2 \mathrm{~A})$; 

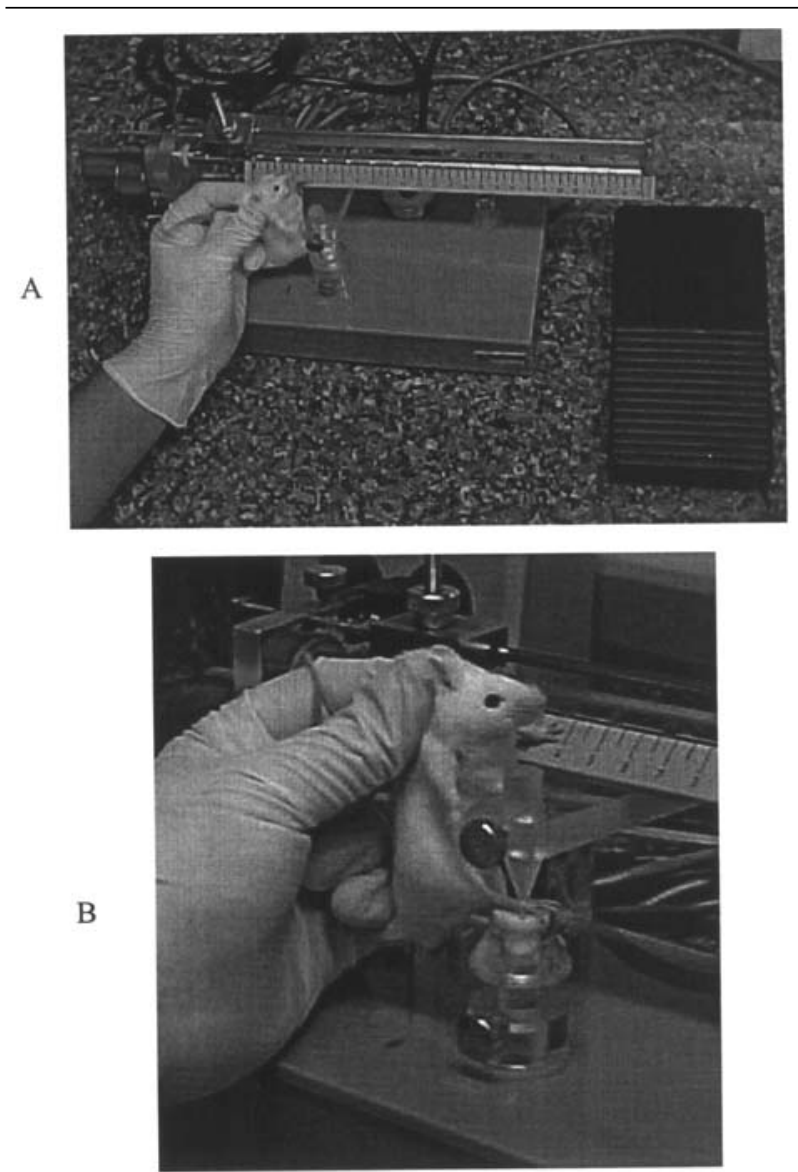

FIGURE 1 Paw withdrawal threshold to pressure (PWTP) test (A). The mouse's hindpaw is placed under a pressure-pad (B) and the force (in grams) applied to obtain limb withdraw is recorded.

at $45 \mathrm{~min}$ for $0.25 \% \mathrm{BVC}_{\mathrm{LUV}}(P<0.01$; Figure $2 \mathrm{~B})$ and at 90,120 and $180 \mathrm{~min}(P<0.05)$ for $0.5 \%$ $\mathrm{BVC}_{\mathrm{LUV}}$ (Figure $2 \mathrm{C}$ ), relatively to their plain solution.

Treatment with $0.5 \% \mathrm{MVC}_{\mathrm{LUV}}$ and $0.5 \% \mathrm{MVC}_{\text {plain }}$ (Figure 3A) showed similar analgesic profiles in the first $120 \mathrm{~min}$ after infiltration, but subsequently $\mathrm{MVC}_{\mathrm{LUV}}$ prolonged analgesia up to $180 \mathrm{~min}$ with differences in the PWTP observed after $150 \mathrm{~min}(P<$ $0.001)$. PWTP were higher from 90 to $180 \mathrm{~min}$ after injection of $1 \% \mathrm{MVC}_{\mathrm{LUV}}$, compared to $\mathrm{MVC}_{\text {plain }}(P<$ 0.05 and $P<0.001$, respectively). At $180 \mathrm{~min}$ a 1.6 times increase in the PWTP was measured; analgesia was prolonged up to $300 \mathrm{~min}$ after $\mathrm{MVC}_{\mathrm{LUV}}$ (Figure 3B). PWTP were higher, from 45 to $240 \mathrm{~min}$ after treatment with $2 \% \mathrm{MVC}_{\mathrm{LUV}}$ in comparison to $2 \%$ $\mathrm{MVC}_{\text {plain }}(P<0.01$ and $P<0.001$, respectively $)$. At 240 min after injection, PWTP was increased 1.4

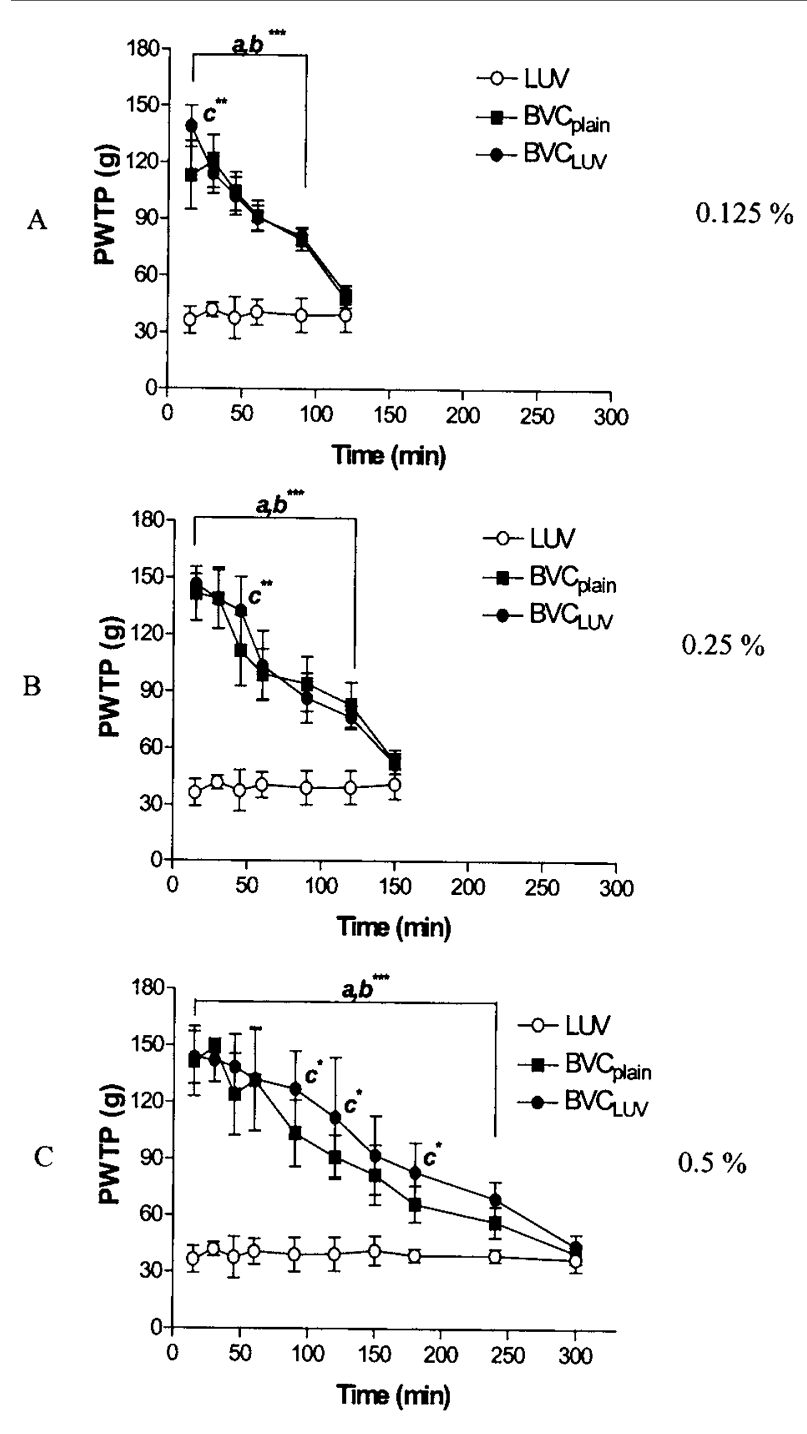

FIGURE 2 Time-course ( $\min$ ) on the paw withdrawal threshold to pressure (PWTP) test showing control group large unilamellar liposomes (LUV), bupivacaine (BVC) $)_{\text {plain }}$ and $\mathrm{BVC}_{\mathrm{LUV}}$ formulations at $0.125 \%(\mathrm{~A}), 0.25 \%(\mathrm{~B})$ and $0.5 \%(\mathrm{C}) \mathrm{BVC}$ concentration. Values are expressed as mean $\pm \mathrm{SD}(n=$ ten per group).

Differences between: a, $\mathrm{BVC}_{\mathrm{LUV}}$ and LUV; $\mathrm{b}, \mathrm{BVC}_{\mathrm{plain}}$ and LUV; c, $\mathrm{BVC}_{\mathrm{LUV}}$ and $\mathrm{BVC}_{\text {plain }} \cdot{ }^{*} P<0.05,{ }^{* *} P<0.01,{ }^{* *} P<0.001$.

times compared to the plain formulation; analgesia was prolonged up to $300 \mathrm{~min}$ (Figure 3C). These data show that infiltration of $\mathrm{MVC}_{\mathrm{LUV}}$ increased the intensity and duration of analgesia up to $240 \mathrm{~min}(0.5 \%, P$ $<0.001)$ and $300 \mathrm{~min}(1 \%$ and $2 \%, P<0.01$ and $P<$ 0.001 , respectively) compared to their plain solution. 


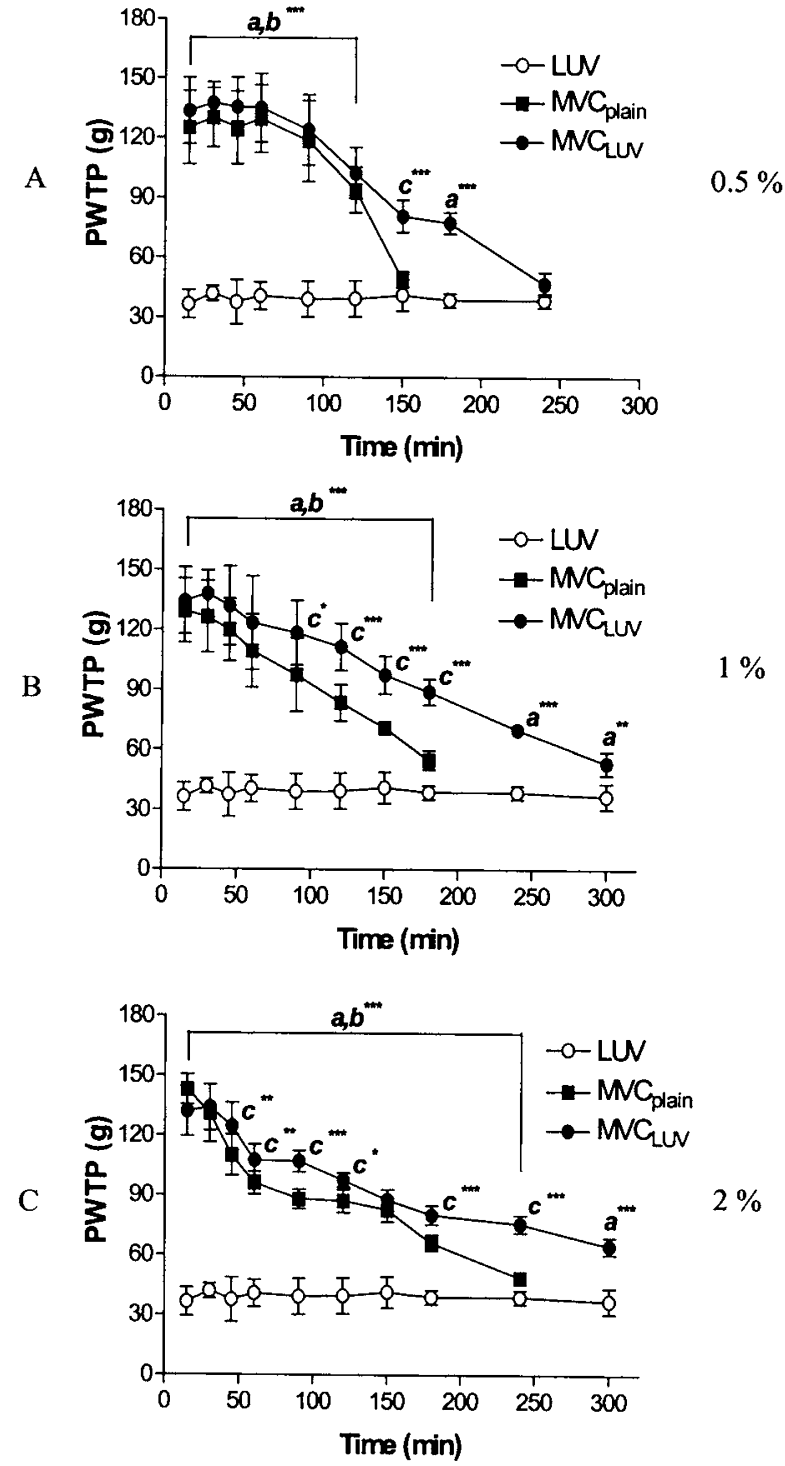

FIGURE 3 Time-course ( $\min$ ) on the paw withdrawal threshold to pressure (PWTP) test showing control large unilamellar liposomes (LUV), mepivacaine (MVC) $)_{\text {plain }}$ and $\mathrm{MVC}_{\mathrm{LUV}}$ formulations at $0.5 \%(\mathrm{~A}), 1 \%(\mathrm{~B})$ and $2 \%(\mathrm{C}) \mathrm{MVC}$ concentration. Values are expressed as mean $\pm \mathrm{SD}$ ( $n=$ ten per group). Differences between: a, $\mathrm{MVC}_{\mathrm{LUV}}$ and LUV; b, MVC $\mathrm{plain}$ and LUV; $\mathrm{c}, \mathrm{MVC}_{\mathrm{LUV}}$ and $\mathrm{MVC}_{\text {plain }} \cdot{ }^{*} P<0.05,{ }^{* *} P<0.01,{ }^{* *} P<0.001$.

\section{Discussion}

The ideal LA must have a long duration of action, low systemic toxicity and selectivity for sensory rather than for motor blockade. In order to achieve this goal, numerous approaches have been used so far, such as the organic synthesis of new LA molecules, the management of LA pH formulations and pharmaceutical associations. In the last decade, the development of LA formulations in carriers - such as liposomes - has provided the possibility to control drug-delivery in biological systems, prolonging the anesthetic effect and/or reducing its toxicity. ${ }^{3}$ Here we studied the encapsulation of BVC and MVC into liposomes. These compounds belong to the cyclic amino-amide series of LA. Despite being chemically related, they exhibit differences in physicochemical properties such as partition coefficients, ${ }^{13}$ ionization and solubility, ${ }^{4-7}$ features that are determinant in their anesthetic potency. ${ }^{1}$

Sciatic nerve blockade was used as an experimental model, providing information about the intensity and duration of blockade induced by LA agents. ${ }^{10}$ Many studies have utilized motor or sensory blockade to assess LA activity in rats ${ }^{14-17}$ and mice. ${ }^{18-20}$ Our experimental model was shown to be appropriate to monitor the duration of motor and sensory blockade induced by LA in mice. Furthermore, the choice of a baseline PWTP was important to limit injury and avoid excessive stimulation of the nociceptors and stress-induced analgesia in mice.

$\mathrm{BVC}_{\mathrm{LUV}}$ and $\mathrm{MVC}_{\mathrm{LUV}}$ were not able to modify the intensity or the duration of LA motor blockade, but $M_{\mathrm{VU}} \mathrm{CUV}_{\mathrm{V}}$ improved the antinociceptive effects on the PWTP test relatively to its plain solution. Our results suggest that the concentration of the anesthetic available at the site of action was improved due to the partition of MVC into LUV. Increasing the local availability of MVC to the nerve fibre, the liposomal formulation enhanced the duration of analgesia and the differential nerve blockade induced by MVC. Controlled release formulations of LA formulations have been used to maintain a high therapeutic index in the treatment of acute pain ${ }^{19}$ or in the management of postsurgical pain, ${ }^{21}$ reducing systemic toxicity and blocking sensory rather than motor fibres. This last feature, analgesia without excessive motor blockade, has enormous clinical relevance. ${ }^{9,21,22}$

Encapsulation of BVC in $\mathrm{MLV}^{21,23,24}$ has been reported to prolong its effects and decrease local/systemic toxicity. ${ }^{25,26}$ Nevertheless our study did not show any improvement in BVC action after encapsulation into LUV, despite the greater osmotic stability of LUV compared with MLV. ${ }^{8,27,28}$ Since the diffusion of drugs in liposomes that have a single lipid bilayer is faster ${ }^{9}$ than that in MLV and also P (partition coefficient) values are smaller, ${ }^{5}$ these should have contributed to the low efficiency of our BVC system. Another consideration is that BVC has a non-ideal partitioning, determined by its non-favourable water 
solubility ${ }^{4-6}$ that can limit its entrance into the membrane. Moreover, our liposomal system was prepared in a different manner than that described previously, in order to carry higher amounts of uncharged BVC. This may explain the differences in analgesic effects observed between BVC liposomal formulations.

Our study suggests that the administration of $0.5 \%$, $1 \%$ and $2 \% \mathrm{MVC}_{\mathrm{LUV}}$ can induce sensory blockade of similar duration to $0.5 \% \mathrm{BVC}_{\text {plain }}$. We suggest that $\mathrm{MVC}_{\mathrm{LUV}}$ is comparable to $\mathrm{BVC}_{\text {plain, }}$, regarding analgesic effects, at clinically relevant concentrations. Duration and intensity of analgesia with MVC was enhanced by encapsulation while this effect was not observed with $\mathrm{BVC}_{\mathrm{LuV}}$. Despite differences between this in vivo model and clinical conditions, encapsulated MVC could be an interesting therapeutic option for the treatment of acute pain, since the duration and intensity of analgesia are comparable to those of BVC.

\section{Acknowledgements}

We would like to thank Dr. N. C. Meirelles (Department of Biochemistry/UNICAMP), Dr. A. R. M. Souza Brito (Department of Physiology) and Dr. A. F. A. Braga (Department of Anesthesiology) for their contributions reviewing this manuscript.

\section{References}

1 Covino BG. Pharmacology of local anaesthetic agents. Br J Anaesth 1986; 58: 701-16.

2 Collins VJ. Principles of Anesthesiology. General and Regional Anesthesia. New York: Lea \& Febiger; 1993.

3 Kuzma PJ, Kline MD, Calkins MD, Staats PS. Progress in the development of ultra-long-acting local anesthetics. Reg Anesth 1997; 22: 543-51.

4 de-Paula E, Schreier S. Molecular and physicochemical aspects of local anesthetic-membrane interaction. Braz J Med Biol Res 1996; 29: 877-94.

5 de Paula E, Schreier $S$. Use of a novel method for determination of partition coefficients to compare the effect of local anesthetics on membrane structure. Biochim Biophys Acta 1995; 1240: 25-33.

6 Fraceto LF, Pinto LM, Franzoni L, et al. Spectroscopic evidence for a preferential location of lidocaine inside phospholipid bilayers. Biophys Chem 2002; 99: 229-43.

7 Pinto LM, Yokaichiya DK, Fraceto LF, de Paula E. Interaction of benzocaine with model membranes. Biophys Chem 2000; 87: 213-23.

8 Mowat JJ, Mok MJ, MacLeod BA, Madden TD. Liposomal bupivacaine. Extended duration nerve blockade using large unilamellar vesicles that exhibit a proton gradient. Anesthesiology 1996; 85: 635-43.

9 Grant GJ, Bansinath M. Liposomal delivery systems for local anesthetics. Reg Anesth Pain Med 2001; 26: 61-3.
10 Leszczynska K, Kau ST. A sciatic nerve blockade method to differentiate drug-induced local anesthesia from neuromuscular blockade in mice. J Pharmacol Toxicol Methods 1992; 27: 85-93.

11 Gantenbein M, Abat C, Attolini L, Pisano P, Emperaire $N$, Bruguerolle $B$. Ketamine effects on bupivacaine local anaesthetic activity and pharmacokinetics of bupivacaine in mice. Life Sci 1997; 61: 2027-33.

12 Randall LO, Selitto JJ. A method for measurement of analgesic activity on inflamed tissue. Arch Int Pharmacodyn Ther 1957; 111: 409-19.

13 Strichartz GR, Sanchez V, Arthur R, Chafetz R, Martin D. Fundamental properties of local anesthetics. II. Measured octanol: buffer partition coefficients and $\mathrm{pK}_{\mathrm{a}}$ values of clinically used drugs. Anesth Analg 1990; 71: 158-70.

14 Grant GJ, Vermeulen K, Zakowski MI, et al. A rat sciatic nerve model for independent assessment of sensory and motor block induced by local anesthetics. Anesth Analg 1992; 75: 889-94.

15 Simonetti MP, Valinetti EA, Ferreira FM. Evaluation of the local anesthetic activity of $\mathrm{S}(-)$ bupivacaine: experimental study in vivo in the rat sciatic nerve (Portuguese). Rev Bras Anestesiol 1997; 47: 425-34.

16 Kohane DS, Lipp M, Kinney RC, Lotan N, Langer $R$. Sciatic nerve blockade with lipid-protein-sugar particles containing bupivacaine. Pharm Res 2000; 17: 1243-9.

17 Estebe JP, Gentili ME, Le Corre P, Le Verge R, Moulinoux JP, Ecoffey C. Sciatic nerve block with bupivacaine-loaded microspheres prevents hyperalgesia in an inflammatory animal model. Can J Anesth 2002; 49: 690-3.

18 Grant GJ, Zakowski MI, Vermeulen K, Langerman L, Ramanathan S, Turndorf $H$. Assessing local anesthetic effect using the mouse tail flick test. J Pharmacol Toxicol Methods 1993; 29: 223-6.

19 Grant GJ, Vermeulen K, Langerman L, Zakowski M, Turndorf $H$. Prolonged analgesia with liposomal bupivacaine in a mouse model. Reg Anesth 1994; 19: 264-9.

20 Grant GJ, Barenholz Y, Piskoun B, Bansinath M, Turndorf H, Bolotin EM. DRV liposomal bupivacaine: preparation, characterization, and in vivo evaluation in mice. Pharm Res 2001; 18: 336-43.

21 Boogaerts JG, Lafont ND, Declercq AG, et al. Epidural administration of liposome-associated bupivacaine for the management of postsurgical pain: a first study. J Clin Anesth 1994; 6: 315-20.

22 Wildsmith JA, Gissen AJ, Takman B, Covino BG. Differential nerve blockade: esters v. amides and the influence of $\mathrm{pK}_{\mathrm{a}}$. Br J Anaesth 1987; 59: 379-84.

23 Malinovsky JM, Le Corre P, Meunier JF, et al. A doseresponse study of epidural liposomal bupivacaine in rabbits. J Control Release 1999; 60: 111-9. 
24 Yu HY, Sun P, Hou Wr. Prolonged local anesthetic effect of bupivacaine liposomes in rats. Int J Pharm 1998; 176: 133-6.

25 Boogaerts J, Declercq A, Lafont N, et al. Toxicity of bupivacaine encapsulated into liposomes and injected intravenously: comparison with plain solutions. Anesth Analg 1993; 76: 553-5.

26 Malinovsky JM, Benhamou D, Alafandy $M$, et al. Neurotoxicological assessment after intracisternal injection of liposomal bupivacaine in rabbits. Anesth Analg 1997; 85: 1331-6.

27 Mui BL, Cullis PR, Evans EA, Madden TD. Osmotic properties of large unilamellar vesicles prepared by extrusion. Biophys J 1993; 64: 443-53.

28 Mui BL, Cullis PR, Pritchard PH, Madden TD.

Influence of plasma on the osmotic sensitivity of large unilamellar vesicles prepared by extrusion. J Biol Chem 1994; 269: 7364-70.

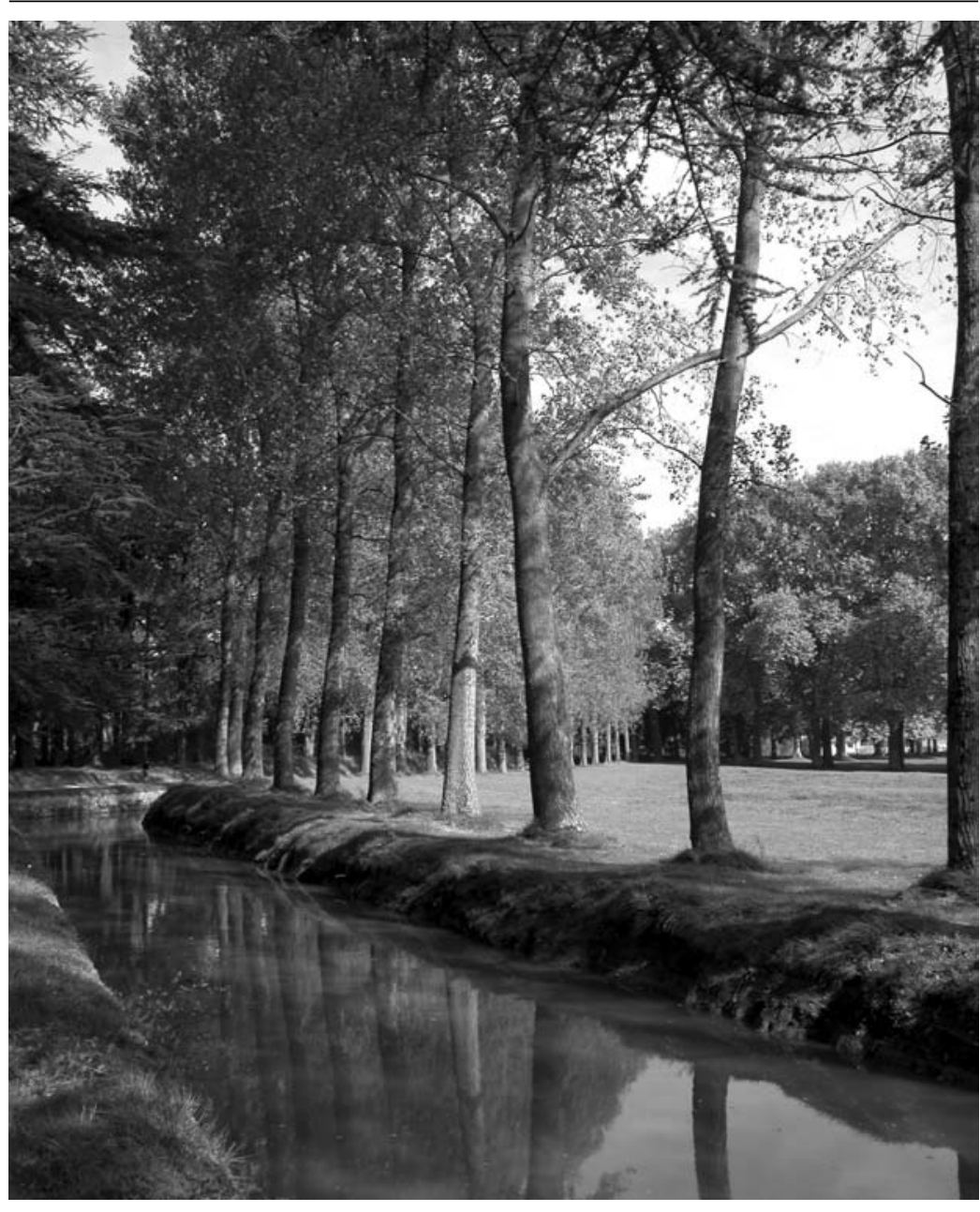

Seuil de Navrouze Canal du midi 